\title{
Population genetic structure of coastal Croatian honeybees (Apis mellifera carnica)*
}

\author{
Irene MUÑOZ ${ }^{1}$, Raffaele DALL'OLIO ${ }^{2}$, Marco LODESANI $^{2}$, Pilar De la RÚA ${ }^{1}$ \\ ${ }^{1}$ Área de Biología Animal, Dpto. de Zoología y Antropología Física, Facultad de Veterinaria, \\ Universidad de Murcia, 30100 Murcia, Spain \\ ${ }^{2}$ CRA-API, Unità di Ricerca di Apicoltura e Bachicoltura. Via di Saliceto, 80, 40128 Bologna, Italy
}

Received 9 October 2008 - Revised 6 March 2009 - Accepted 12 March 2009

\begin{abstract}
The genetic structure and molecular diversity of Croatian honeybee coastal populations have been investigated with microsatellite and mitochondrial markers. According to sequence data of the mitochondrial tRNA ${ }^{\text {leu }}$-cox2 intergenic region, all analysed samples belong to the Central Mediterranean and Southeast European evolutionary C-lineage. Four mitochondrial haplotypes have been found in the Croatian honeybees, whereas two newly described have been found in Croatia and Greek respectively. Through the Bayesian analysis of microsatellite variation, two groups can be distinguished within the Croatian honeybee population, suggesting the existence of two subpopulations of A. m. carnica. The relation of these subpopulations with previously described ecotypes and regional variations is discussed. These results emphasize the importance of sequencing in the description of new haplotypes and therefore, in the inference of molecular biodiversity within honeybee populations. The description of two subpopulations in coastal Croatian honeybees must be considered in future conservation strategies.
\end{abstract}

\section{honeybees / mitochondrial DNA / microsatellites / population structure / Croatia}

\section{INTRODUCTION}

The natural distribution area of Apis mellifera L. include Africa, Europe and Western Asia. In these geographical areas exist races or subspecies, which are locally adapted to environmental conditions (Ruttner, 1988). Based on morphological and ecological data, 29 honeybee subspecies have been recognised (Engel, 1999; Sheppard and Meixner, 2003) and grouped in four morphological branches (Ruttner, 1988). The morphometric branch-C consisted of five honeybee subspecies: A. $m$. siciliana Grassi (later included in the African evolutionary A-lineage based on molecular analyses, Sinacori et al., 1998), A. m. ligustica Spinola, A. m. cecropia Kiensenwetter,

Corresponding author: P. De la Rua, pdelarua@um.es

* Manuscript editor: Stefan Fuchs
A. m. macedonica Ruttner and A. m. carnica Pollman (Ruttner, 1988, named after Engel, 1999). The natural distribution of the Carniolan honeybee (A. m. carnica) covers the Balkan region from Eastern Austria, Slovenia, down to Croatia and to a lesser extent Hungary and Bulgaria (Ruttner, 1988). This subspecies is appreciated for its gentleness and easy managment for honey production and crop pollination and, therefore, has been introduced in other European countries, such as Germany and other continents, including Australia and the Americas (Moritz et al., 2005).

Croatia contains a range of variable climates and habitats. Therefore, knowledge of its honeybee population is important to gain understanding of overall honeybee biogeography. In relation to climatic and geographical variability, three ecotypes of the Carniolan bee (Pannonian, Subalpin and Dalmatian) were morphologically described (Ruttner, 1988), 
Table I. Details of samples location, number of analyzed colonies (n) and haplotypes in each location. Number in brackets referred to the locations showed in Figure 1.

\begin{tabular}{|c|c|c|c|c|c|c|c|c|}
\hline Location & Latitude & Longitude & $\mathrm{n}$ & $\mathrm{C} 1$ & $\mathrm{C} 2 \mathrm{c}$ & $\mathrm{C} 2 \mathrm{~d}$ & $\mathrm{C} 2 \mathrm{e}$ & $\mathrm{C} 2 \mathrm{i}$ \\
\hline Istra Pidzan (1) & $45^{\circ} 12^{\prime} 4.79^{\prime \prime} \mathrm{N}$ & $14^{\circ} 2^{\prime} 18.71 " \mathrm{E}$ & 4 & 1 & & & 3 & \\
\hline Mali Losini (2) & $44^{\circ} 31^{\prime} 46.57^{\prime \prime N}$ & $14^{\circ} 27^{\prime} 52.47^{\prime \prime} \mathrm{E}$ & 4 & & 1 & 1 & 2 & \\
\hline Sutivanac (3) & $45^{\circ} 6^{\prime} 17.95^{\prime \prime} \mathrm{N}$ & $13^{\circ} 57^{\prime} 45.29^{\prime \prime} \mathrm{E}$ & 4 & 4 & & & & \\
\hline Brac (4) & $43^{\circ} 19^{\prime} 33.11 " \mathrm{~N}$ & $16^{\circ} 46^{\prime} 53.57^{\prime \prime} \mathrm{E}$ & 4 & 2 & 2 & & & \\
\hline Korcula (5) & $42^{\circ} 56^{\prime} 52.59^{\prime \prime} \mathrm{N}$ & $17^{\circ} 7 ’ 35.26 " \mathrm{E}$ & 4 & & & & 4 & \\
\hline Nuoro (6) & $40^{\circ} 19^{\prime} 15.62^{\prime \prime} \mathrm{N}$ & $9^{\circ} 19^{\prime} 49.57 " \mathrm{E}$ & 3 & 3 & & & & \\
\hline Sanluri (7) & $39^{\circ} 33^{\prime} 49.53^{\prime \prime} \mathrm{N}$ & $8^{\circ} 53^{\prime} 58.93 " \mathrm{E}$ & 3 & 3 & & & & \\
\hline Cagliari (8) & $40^{\circ} 50^{\prime} 23.99^{\prime \prime} \mathrm{N}$ & $14^{\circ} 15^{\prime} 10.34^{\prime \prime} \mathrm{E}$ & 2 & 2 & & & & \\
\hline Orio Canavese (9) & $45^{\circ} 19^{\prime} 49.20^{\prime \prime} \mathrm{N}$ & $7^{\circ} 51^{\prime} 46.13^{\prime \prime} \mathrm{E}$ & 3 & 3 & & & & \\
\hline Camugnano (10) & $44^{\circ} 10^{\prime} 19.15^{\prime \prime} \mathrm{N}$ & $11^{\circ} 5^{\prime} 3.42^{\prime \prime} \mathrm{E}$ & 4 & 4 & & & & \\
\hline Perugia (11) & $43^{\circ} 6^{\prime} 38.52^{\prime \prime} \mathrm{N}$ & $12^{\circ} 23^{\prime} 21.02^{\prime \prime} \mathrm{E}$ & 3 & 3 & & & & \\
\hline Caserta (12) & $41^{\circ} 4^{\prime} 31.49^{\prime \prime} \mathrm{N}$ & $14^{\circ} 19^{\prime} 55.90^{\prime \prime} \mathrm{E}$ & 2 & 2 & & & & \\
\hline Chalkidiki (13) & $40^{\circ} 16^{\prime} 57.99^{\prime \prime} \mathrm{N}$ & $23^{\circ} 40^{\prime} 58.82^{\prime \prime} \mathrm{E}$ & 1 & & & 1 & & \\
\hline Larissa (14) & $39^{\circ} 43^{\prime} 19.86^{\prime \prime} \mathrm{N}$ & $22^{\circ} 25^{\prime} 56.49^{\prime \prime} \mathrm{E}$ & 1 & & & 1 & & \\
\hline Ikaria (15) & $37^{\circ} 36^{\prime} 9.23^{\prime \prime} \mathrm{N}$ & $26^{\circ} 10^{\prime} 6.33^{\prime \prime} \mathrm{E}$ & 1 & & & & & 1 \\
\hline Astypalaia (16) & $36^{\circ} 34^{\prime} 26.76^{\prime \prime} \mathrm{N}$ & $26^{\circ} 22^{\prime} 15.56^{\prime \prime} \mathrm{E}$ & 1 & & & 1 & & \\
\hline Karpathos (17) & $35^{\circ} 42^{\prime} 0.00^{\prime \prime} \mathrm{N}$ & $27^{\circ} 8^{\prime} 60.00^{\prime \prime} \mathrm{E}$ & 1 & & & 1 & & \\
\hline
\end{tabular}

although later the same author inferred the existence of only Alpine and Pannonian ecotypes and several regional variations such as Dalmatian (Ruttner, 1992). Recent genetic studies with both microsatellite and mtDNA markers (Sušnik et al., 2004) were unable to distinguish Croatian bees from Slovenian bees, probably because the beekeepers from both countries exchange honeybees. At the mtDNA level, a single haplotype $(\mathrm{C} 2 \mathrm{c})$ has been detected in populations from both countries.

Some mitochondrial haplotypes can be differentiated through variation in the mitochondrial tRNA ${ }^{\text {leu }}$-cox 2 intergenic region (Garnery et al., 1993, 1995, 1998; De la Rúa et al., 1998, 1999, 2000; Franck et al., 1998, 2000a, 2000b; Cánovas et al., 2008). Subspecies belonging to the $\mathrm{C}$ evolutionary lineage show a short sequence and absence of length variability in the tRNA ${ }^{\text {leu }}$-cox 2 intergenic region. Therefore, only five haplotypes have been reported to date, exclusively based on five single nucleotide polymorphisms (Franck et al., 2000a, 2000b; Sušnik et al., 2004). Consequently sequence data from this conservative mtDNA region are more useful than length polymorphism to estimate molecular variability within $\mathrm{C}$ lineage subspecies. Microsatellite variation is also suitable to detect recent population events, including introgression (Jensen et al., 2005) and admixture of local and introduced honeybee populations (De la Rúa et al., 2001).

The aim of the present study was to assess the genetic variability of Croatian honeybee coastal populations to increase the overall genetic knowledge of the subspecies A. m. carnica and to seek molecular evidence for the aforementioned ecotypes and regional variation. For appropriate comparisons within Cbranch taxa, samples from Italy $(A$. $m$. ligustica) and Greece (A. m. macedonica) were also included in the analyses.

\section{MATERIAL AND METHODS}

\subsection{Sampling and DNA extraction}

Adult honeybee workers were sampled from 45 colonies in Croatia $(\mathrm{N}=20)$, Italy $(\mathrm{N}=20)$ and Greece ( $N=5)$, during 2006-2008 at seventeen different locations (Tab. I, Fig. 1). Samples were preserved in absolute ethanol and kept at $-20{ }^{\circ} \mathrm{C}$ until they were processed in the laboratory.

A single honeybee worker per colony was used for mtDNA analysis $(\mathrm{N}=45)$, while five honeybee workers per colony ( $\mathrm{N}=225$, but see results) were 


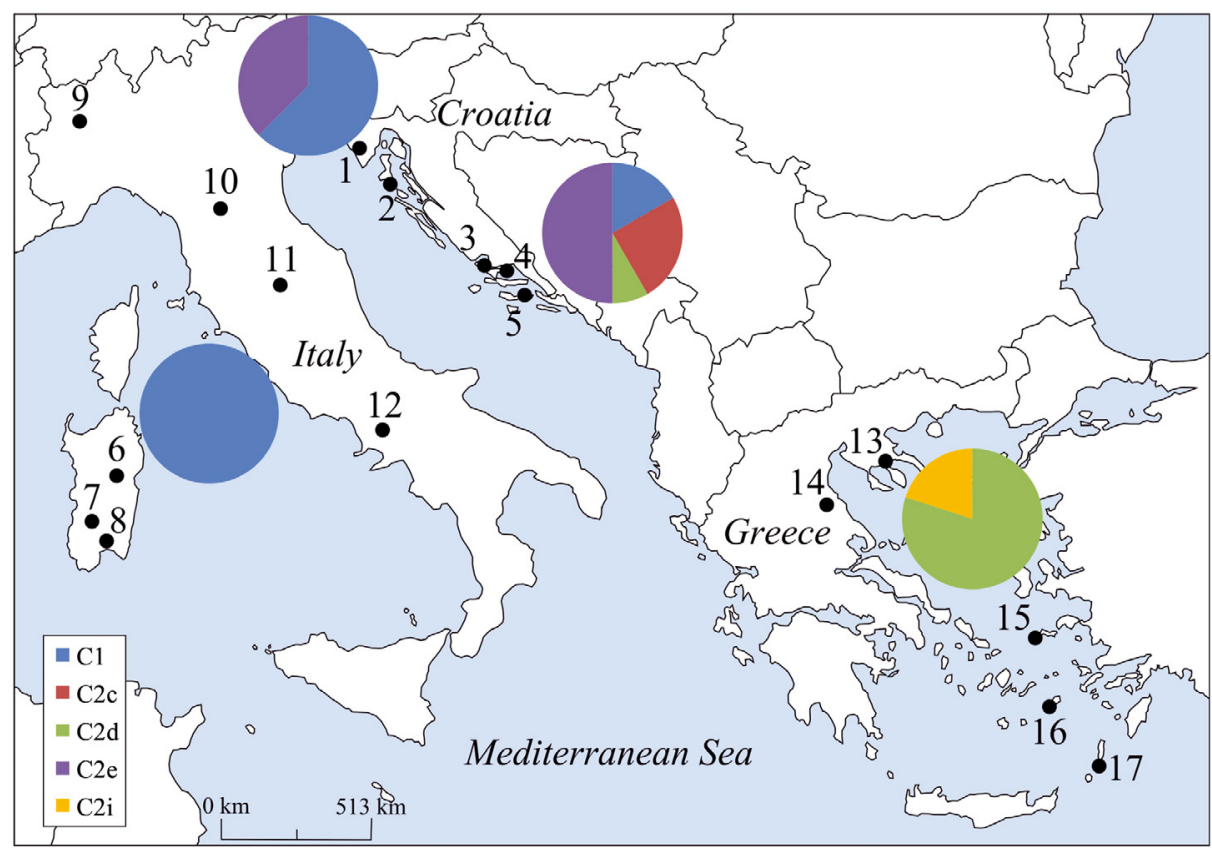

Figure 1. Map of East Europe with the distribution of haplotypes in the Croatian subpopulations 1 and 2 and the reference Italian and Greek populations. Sampling sites names are showed in Table I.

used for microsatellite analysis. Total DNA was extracted from three right legs each honeybee worker using a 5\% Chelex solution (Walsh et al., 1991).

\subsection{Mitochondrial DNA analysis}

The tRNA $^{\text {leu }}-\operatorname{cox} 2$ intergenic region were PCR amplified with the primers E2 (5'GGCAGAATAAGTGACATTG-3') located at the $5^{\prime}$ end of the gene tRNA $^{\text {leu }}$ and $\mathrm{H} 2$ (5'- $^{\prime}$ CAATATCATTGATGAACC-3') located close to the 5' end of the gene cox2 (Garnery et al., 1991) in a total volume of $25 \mu \mathrm{L}$, following the conditions described by Garnery et al. (1993). To determine the amplicon size, aliquots of $3 \mu \mathrm{L}$ of each sample were run on a $1.5 \%$ agarose gel, stained with ethidium bromide and photographed over a UV light screen. Twenty-two $\mu \mathrm{L}$ of the PCR product were then digested with $\operatorname{DraI}$ and separated by 4\% Nusieve gel electrophoresis to reveal RFLPs. Amplicons of each sample were purified with isopropanol and ammonium acetate and submitted to sequencing (Secugen S.L., Madrid, Spain) with the primer E2.

Each sequence was manually checked for base calling then a multiple sequence alignment was per- formed with the program MEGA version 4 (Tamura et al., 2007) including for comparison published sequences (Franck et al., 2000b; Sušnik et al., 2004).

\subsection{Microsatellite analysis}

Multiplex PCR reaction with five microsatellite loci A7, A113, Ap43, Ap55 and B124 (Estoup et al., 1995), was performed in $10 \mu \mathrm{L}$ total volume containing $50 \mathrm{mM} \mathrm{KCl}, 10 \mathrm{mM}$ Tris $\mathrm{HCl}(\mathrm{pH} \mathrm{9.0)}$ ), $1.2 \mathrm{mM} \mathrm{MgCl} 2,0.3 \mu \mathrm{M}$ of each dNTP, $0.8 \mu \mathrm{M}$ of each primer, 1.5 units of $\mathrm{Taq}$ polymerase (Bioline) and $2 \mu \mathrm{L}$ of DNA extract. Annealing temperature was set at $54{ }^{\circ} \mathrm{C}$. PCR products were visualized by capillary electrophoresis and sized with an internal size-standard (Servei Central de Suport a la Investigació Experimental, University of Valencia, Spain). Alleles were subsequently scored using GeneMapper v3.7 software (Applied Biosystems).

\subsection{Analysis of microsatellite data}

Population genetic parameters were calculated with GenAlex (Peakall and Smouse, 2006). Genetic 
diversity within populations was evaluated by computing allele frequencies, observed (Ho) and expected $(\mathrm{He})$ heterozygosity. Hardy-Weinberg equilibrium was tested with Genepop (Raymond and Rousset, 1995).

A Bayesian model-based clustering method for inferring population structure and assignment of individuals to populations probabilistically based on their multilocus genotypes, and thereby estimates of the posterior probability for a given number of genetic populations $(K)$ were obtained with the software STRUCTURE v 2.2 (Pritchard et al., 2000). An admixture model assuming correlated allele frequencies was used. The results were based on simulations of 80000 burn-in steps and 1000000 MCMC (Markov Chain Monte Carlo algorithm) iterations. Five runs for each $K$-value $(K=1-10)$ were used to estimate the most likely value of $K$. The number of populations was defined using the value of $\Delta K$ as described in Evanno et al. (2005).

Principal coordinates analysis (PCA) via covariance with standardization of the individual genetic distances was performed to find and plot the relationships between the individuals belonging to the different populations and inferred subpopulations.

\section{RESULTS}

\subsection{Mitochondrial DNA}

The DraI-test can discriminate between the major mitochondrial lineages of A. mellifera. However insertions, deletions or single point mutations not directly involved in the restriction sites, can only be detected by sequencing. The analysis of sequence data at the intergenic region produced five different haplotypes all of them ascribable to the East European Clineage and characterized by the presence of a single $\mathrm{Q}$ sequence: four have been found in Croatia, three of them $(\mathrm{C} 1, \mathrm{C} 2 \mathrm{c}$ and $\mathrm{C} 2 \mathrm{~d})$ previously described (Franck et al., 2000b; Sušnik et al., 2004), and one (C2e) new. A fifth haplotype (C2i) was newly described in Greek samples (GenBank accession numbers FJ824582, FJ824583, FJ824584, FJ824585, FJ824586 and FJ824587).

A total of seven polymorphic sites were found among the sequences of 572-570 bp (Fig. 2) and named following Franck et al. (2000b). The polymorphic site 1 , showed a single nucleotide deletion that provided diagnostic differentiation between the $\mathrm{C} 1$ and $\mathrm{C} 2$ haplotypes, while the remaining positions allowed us to distinguish among different types of $\mathrm{C} 2$ haplotype. The new haplotypes $\mathrm{C} 2 \mathrm{e}$ and $\mathrm{C} 2 \mathrm{i}$ were distinguishable from $\mathrm{C} 2 \mathrm{~d}$ because of a single nucleotide deletion and a $\mathrm{G} \rightarrow \mathrm{A}$ transition at the polymorphic sites 3 and 5, respectively.

Haplotype distribution per locality is detailed in Table I. The four haplotypes detected in Croatia had the following overall frequencies: 0.45 (C2e), 0.35 (C1), 0.15 (C2c) and $0.05(\mathrm{C} 2 \mathrm{~d})$. All Italian samples bore the same $\mathrm{C} 1$ haplotype, while two haplotypes were found in Greece, $(\mathrm{C} 2 \mathrm{~d}$ and $\mathrm{C} 2 \mathrm{i}$ with a frequency of 0.80 and 0.20 respectively) (Fig. 1).

\subsection{Population structure based on microsatellite data}

Only those samples that amplified three or more loci were included in the analyses $(90 \%$ of Croatian, $67 \%$ of Italian and $76 \%$ of Greek samples).

The number of scored alleles at the five microsatellite loci varied from five (loci A113 in Italy and Ap55 in Greece) to 16 (locus A7 in Croatia). The average allele number within population varied between 9.6 (Italy) and 11.0 (Croatia). Gene diversity measured as expected heterozygosity $(\mathrm{He})$ ranged from 0.645 (Italy) to 0.796 (Greece) on average (Tab. II). Honeybee populations from Greece and Croatia deviated significantly from the Hardy-Weinberg equilibrium $(P<0.05)$.

Population genetic structure was inferred through the Bayesian clustering method: the highest posterior probability of the data set was detected when using a model that assumed four populations (Evanno et al., 2005). The Croatian population was split into two separate subpopulations: 1 spread at the north (IstraPidzan and Mali Losini) and 2 distributed at the south (Sutivanac, Brac and Korcula). These subpopulations showed different level of influence of the Italian population, while a small fraction of the Greek population showed influence of the subpopulation-1 of Croatian honeybees (Fig. 3). 


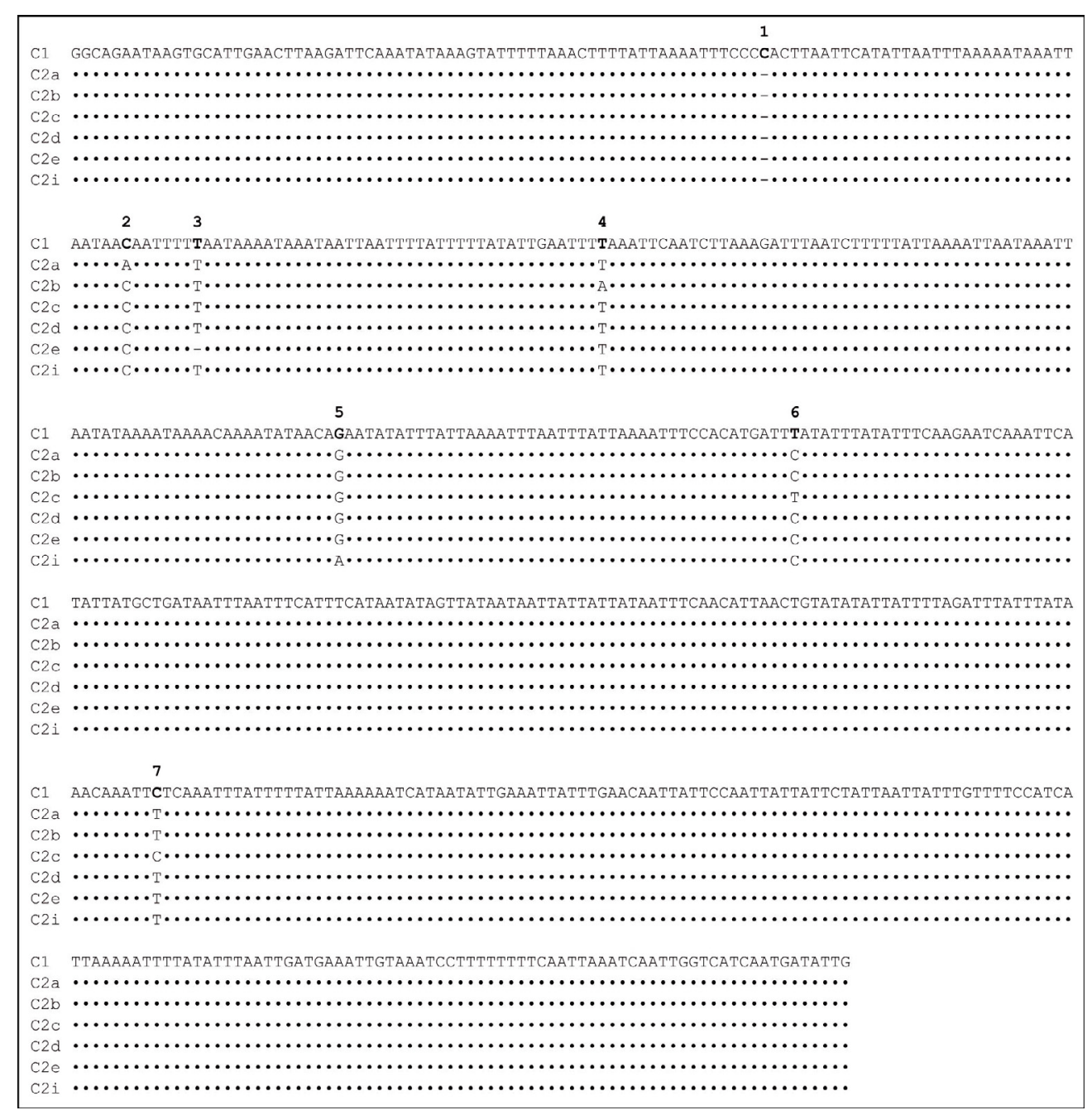

Figure 2. Sequence of the $\mathrm{tRNA}^{\text {leu }}$-cox 2 intergenic regions of the $\mathrm{C}$ haplotypes $(\mathrm{C} 1$ sequence corresponds to the mtDNA fragment from positions 3363-3935 bp published by Crozier and Crozier, 1993). C1, C2a and C2b haplotypes were described by Franck et al. (2000b) and C2c and C2d haplotypes by Sušnik et al. (2004). C2i are newly described in this work. Numbers correspond to variable polymorphic sites (in bold) (GenBank accession numbers FJ824582, FJ824583, FJ824584, FJ824585, FJ824586 and FJ824587).

A principal coordinate analysis (PCA) based on the first two principal coordinates was performed to investigate population patterns based on the genetic distance among individual samples (Fig. 4). Samples from Croatian subpopulation-1 were located in the quadrant 4 together with the samples from Greece, samples from Croatian subpopulation2 were located in quadrant 3 with a few samples in the quadrant 2, Italian samples were grouped in a separate cluster located between the quadrants $1-2$, being a few of them spread to the quadrant 3 .

\subsection{Introgression and hybridization}

Assignment test (GeneAlex) allocated seven Italian individuals to the Croatian subpopulation-2 and four Greek individuals 
Table II. Microsatellite variation in Croatian, Italian and Greek A. mellifera populations. Sample size (N), number of detected alleles (n), observed (Ho) and expected (He) heterozygosity per locus and mean values \pm SD by population.

\begin{tabular}{lccccc}
\hline Pop & Locus & $\mathrm{N}$ & $\mathrm{n}$ & Ho & He \\
\hline Croatia & A113 & 91 & 12 & 0.549 & 0.724 \\
& A7 & 91 & 16 & 0.846 & 0.830 \\
& Ap43 & 90 & 9 & 0.722 & 0.773 \\
& Ap55 & 90 & 11 & 0.622 & 0.633 \\
& B124 & 89 & 7 & 0.629 & 0.637 \\
Italy & Mean \pm SD & $90.200 \pm 0.374$ & $11.000 \pm 1.517$ & $0.674 \pm 0.051$ & $0.719 \pm 0.038$ \\
& A113 & 67 & 5 & 0.328 & 0.402 \\
& A7 & 66 & 11 & 0.818 & 0.826 \\
& Ap43 & 67 & 13 & 0.642 & 0.599 \\
& Ap55 & 66 & 11 & 0.788 & 0.820 \\
& B124 & 67 & 8 & 0.612 & 0.578 \\
& Mean \pm SD & $66.600 \pm 0.245$ & $9.600 \pm 1.400$ & $0.638 \pm 0.087$ & $0.645 \pm 0.080$ \\
& A113 & 19 & 9 & 0.842 & 0.823 \\
& A7 & 19 & 16 & 0.947 & 0.893 \\
& Ap43 & 19 & 13 & 0.737 & 0.846 \\
& Ap55 & 19 & 5 & 0.526 & 0.630 \\
& B124 & 19 & 8 & 0.737 & 0.787 \\
& Mean \pm SD & $19.000 \pm 0.000$ & $10.200 \pm 1.934$ & $0.758 \pm 0.070$ & $0.796 \pm 0.045$ \\
\hline
\end{tabular}

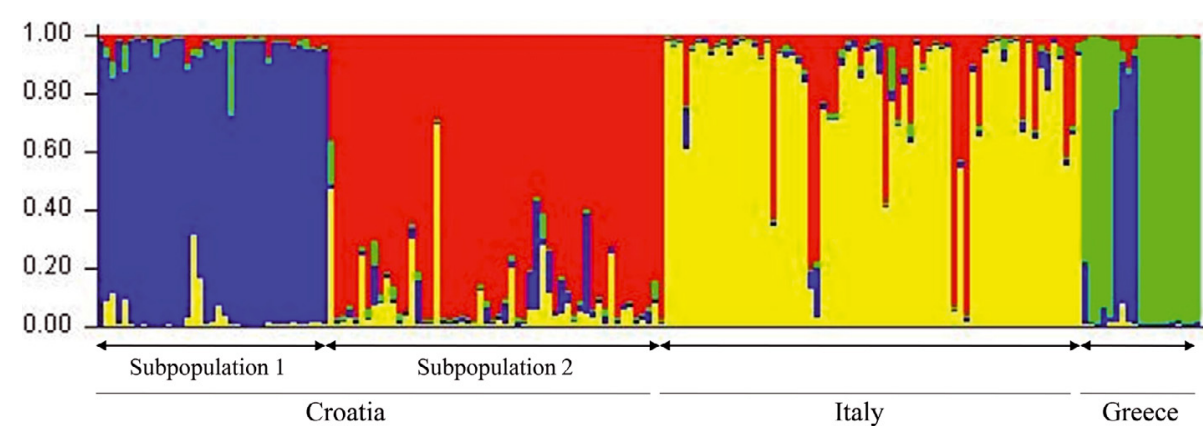

Figure 3. Results of STRUCTURE analysis using admixture and correlated allele frequencies models. Individuals are represented by vertical lines, grouped by inferred populations $(K=4)$. Division of individuals into coloured segment represents the assignment probability of that individual to each of the K groups.

to the Croatian subpopulation-1, while one and two individuals of the Croatian subpopulations 1 and 2 respectively, were assigned to the Italian population.

These data were corroborated with the STRUCTURE software (Tab. III). When the distribution of the individual admixture proportions in pre-defined populations (Italy, Greece and Croatia) was analysed using the admixture and correlated allele frequency models and the four inferred populations $(\mathrm{K}=$ 4 ), most of the Croatian samples were shared in two subpopulations (Croatia- $1=51.7 \%$ and
Croatia- $2=39.9 \%$ ) while the remaining $6.3 \%$ of individuals were assigned to the Italian cluster; moreover, $19.7 \%$ of individuals of the Greek population and $14.7 \%$ of the Italian individuals were assigned to Croatian 2 and 1 inferred subpopulations, respectively.

\section{DISCUSSION}

Molecular genetic markers provide insights into the geographical distribution of the genetic diversity of $A$. mellifera subspecies. 


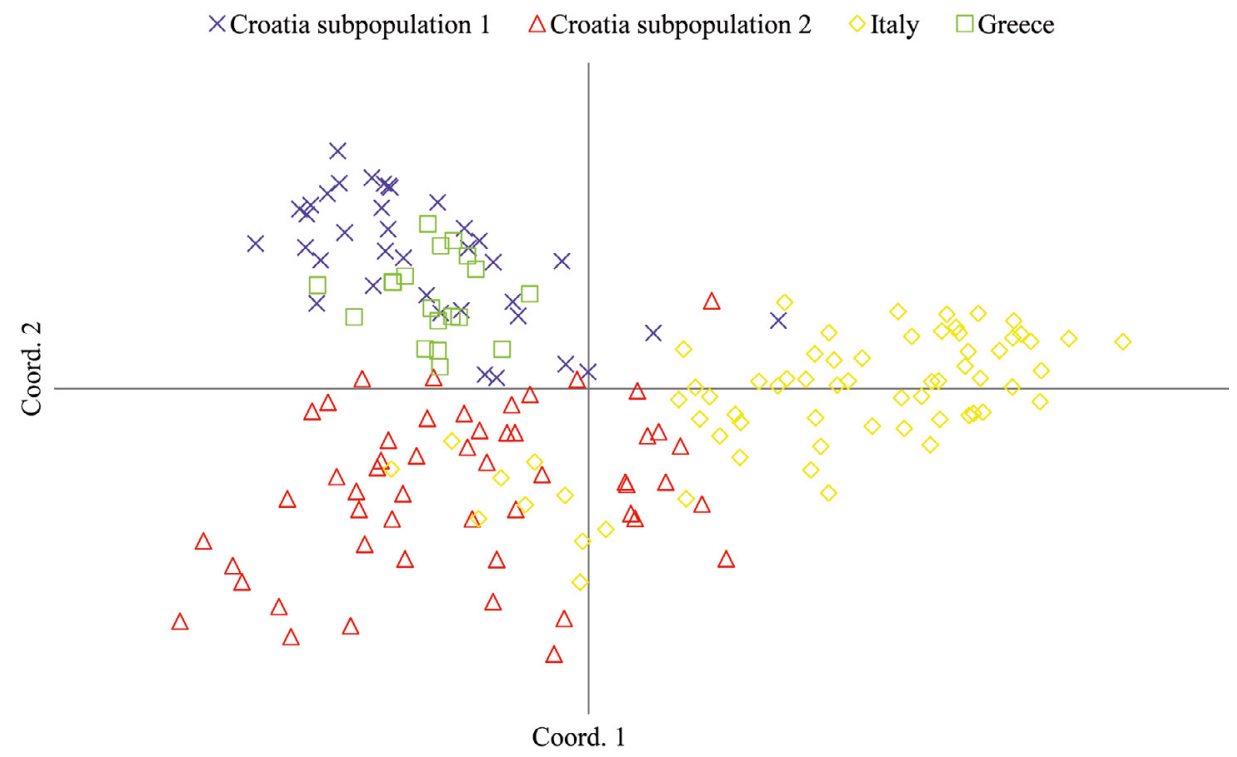

Figure 4. Distribution of A. mellifera individuals based on the genetic distance analysed with principal coordinate analysis (PCA).

Table III. Proportion of membership of each pre-defined population (Croatia, Italy and Greece) to each of the four inferred populations $(K=4)$. Pairwise analyses were performed with STRUCTURE exploring admixture and correlated allele frequency models. $\mathrm{N}=$ number of individuals.

\begin{tabular}{llllll}
\hline \multirow{2}{*}{ Pre-defined } & \multicolumn{5}{c}{ Inferred population } \\
\cline { 2 - 5 } & $\mathrm{N}$ & Croatia-1 & Croatia-2 & Italy & Greece \\
population & & & & & \\
Croatia & 91 & 0.517 & 0.399 & 0.063 & 0.021 \\
Italy & 67 & 0.147 & 0.025 & 0.815 & 0.013 \\
Greece & 19 & 0.019 & 0.197 & 0.014 & 0.770 \\
\hline
\end{tabular}

The assessment of present population structure is an essential knowledge for an effective management policy. In this work we analyzed mitochondrial and nuclear DNA markers to study the population structure of honeybees from coastal Croatia. Both marker sets showed that the situation of the Croatian honeybees was more complex than expected from previous published data.

In the intergenic tRNA ${ }^{\text {leu }}$-cox 2 region, two new polymorphic sites were detected (one deletion and one transition), in addition to the five already observed in the A. mellifera subspecies of the $\mathrm{C}$ evolutionary lineage (Franck et al., 2000b; Sušnik et al., 2004), thus increasing the known molecular variation within this lineage. Four out of the seven C-haplotypes known to date have been found in Croatia, whereas Sušnik et al. (2004), in their study about the molecular variation of A. m. carnica in Slovenia that also included ten samples from Croatia, reported only one (C2c). Haplotype $\mathrm{C} 2 \mathrm{c}$ was also detected in the present study but with a lower frequency, thus partially confirming the conclusion reached by Sušnik et al. (2004) about the close relationship between Slovenian and Croatian bees. These results are likely due, among other things, to the 
bi-directional commercial exchanges between beekeepers.

Ruttner (1992) described the presence of two morphologically distinct ecotypes of $A$. $m$. carnica according to zoogeographic zones named Alpine and Pannonian, and a regional variation called Dalmatian spread in the Adriatic seaside of Croatia. Although we lack samples from the Alpine (Austria and Slovenia) and the Pannonian regions (Hungary and Romania) with which to compare, our molecular analyses did demonstrate the presence of two different Croatian subpopulations within the Dalmatian variation. Based on the geographic origin of our samples, the subpopulation-1 corresponds to Northern (Istra Pidzan and Mali Losini) and the subpopulation-2 to Southern localities (Sutivanac, Brac and Korcula). Both subpopulations present different haplotype frequency, with C2e being more frequent at the Northern than at the Southern subpopulation.

Microsatellite analyses also supported this distinction and suggest that both subpopulations were (or still are) subject to introgression events from neighbouring $A$. mellifera subspecies. Introgression from Italian $A$. $m$. ligustica might have occurred mainly in the subpopulation- 2 in congruence with the occurrence of the haplotype $\mathrm{C} 1$ characteristic of A. m. ligustica. These results suggest that introductions of honeybees from neighbouring countries occur, in contrast to the conclusion depicted by Sušnik et al. (2004). This introduction could be either due to natural migration, with Italian honeybees that have flown across the Adriatic Sea using the islands as stepping stones (the average distance from the Croatian coast to Italy is $160 \mathrm{~km}$, but at some Northern points only $40-80 \mathrm{~km}$ separate both coasts, being a flying distance for a honeybee swarm with the help of summer west winds) or through human-mediated queen trade. This putative gene flow could happen in both directions as depicted from the microsatellite analyses. Although not a single C2 haplotype has been observed in Italy (Franck et al., 2000a, present data), genetic introgression from the Croatian subpopulation-2 into the Italian population was inferred from the Bayesian analysis of the microsatellite variation, and the assignment test that predicts that $14.7 \%$ of the
Italian bees had a Croatian origin. We hypothesise that the introgression is produced by Croatian drones mating Italian queens. Evidence of $A$. $m$. carnica introgression into A. $m$. ligustica has been demonstrated by Dall'Olio et al. (2007), not only in the northern natural hybridization zone, but also further south. This introgression may result from either natural migration or transport by beekeepers or both.

The haplotype $\mathrm{C} 2 \mathrm{~d}$, which is the most frequent in the Greek population, was observed in only one colony in the Croatian subpopulation-1. This fact and the gene flow inferred from the STRUCTURE and assignment test analyses, suggests the introduction of honeybees from the neighbouring $A$. $m$. macedonica Greek populations.

In conclusion, the analysis of Croatian honeybees with molecular markers provides additional evidence of the variation evident in the sequence of the intergenic tRNA ${ }^{\text {leu }}$ $\operatorname{cox} 2$ region and its usefulness to study genetic diversity among and within A. mellifera evolutionary lineages. Biodiversity found in this region enhances the need to conduct similar analyses (with both microsatellite markers and mitochondrial sequence data), in honeybee populations from neighbouring regions where major sources of the autochthonous Carnolian bee still remain.

\section{ACKNOWLEDGEMENTS}

Thanks are due to N. Kezic, F. Hatjina and M. Bouga for their help in providing samples. P. De la Rúa and I. Muñoz are supported by programs of the Spanish Ministry of Science and Innovation. The editor S. Fuchs and one reviewer made useful comments that improve the manuscript.

Structure génétique des populations d'abeilles (Apis mellifera) de la côte croate.

génétique population / microsatellite / ADN mitochondrial / Croatie / variabilité génétique

Zusammenfassung - Genetische Struktur der Bienenpopulation der kroatischen Küste (Apis mellifera carnica). Das Ziel dieser Untersuchung ist eine Einschätzung der genetischen Variabilität 
der kroatischen Honigbiene und die Suche nach molekularen Belegen für bereits auf der Basis von morphometrischen und ökologischen Daten beschriebene Ökotypen und regionale Variationen (Ruttner, 1992). Zu Vergleichszwecken wurden Proben aus Italien und Griechenland ebenfalls analysiert.

Zur Erforschung der Biogeographie von Apis mellifera wird im wesentlichen die Analyse der Variabilität der mitochondrialen DNA herangezogen, während die Struktur von Populationen aus der Analyse von Mikrosatelliten abgeleitet wird. Die anerkannten 29 Unterarten der Honigbiene (Engel, 1999; Sheppard und Meixner, 2003) wurden in fünf evolutionäre Linien eingruppiert (Garnery et al., 1992; Estoup et al., 1995; Franck et al., 2000b; Whitfield et al., 2006), von denen vier natürlicherweise im Mittelmeerbecken vorkommen: M (Westund Nordeuropa), $\mathrm{C}$ (Zentrales Mittelmeer und Südosteuropa), O (Naher Osten) und A (Afrika).

Fünfundvierzig Bienenvölker aus Kroatien, Italien und Griechenland wurden untersucht (Tab. I und Abb. 1), die nach Ergebnissen von Sequenzdaten der mitochondrialen tRNA ${ }^{\text {leu }}-\operatorname{cox} 2$ Region alle zur mitochondrialen C-Linie gehören. Zwei neue mtDNA Haplotypen, C2e und C2i wurden in Kroatien, bzw. in Griechenland, gefunden, während alle italienischen Proben den C1 Haplotypen aufwiesen. In Kroatien wurden vier Haplotypen mit unterschiedlichen Häufigkeiten nachgewiesen: $\mathrm{C} 1$ (0.35), C2c (0.15), C2d (0.05), und C2e (0.45). In Griechenland war der Haplotyp C2d (0.80) häufiger als Typ C2i (0.20) (Abb. 1).

In der Bayesschen Analyse der Mikrosatelliten auf der Basis von vier Gruppen wurde die kroatische Bienenpopulation in zwei Untergruppen mit einer mehr nördlichen bzw. mehr südlichen Verbreitung aufgeteilt (Kroatien-1 $=51,7 \%$ und Kroatien-2 = $39,9 \%$ ), wobei jedoch 6,3\% der kroatischen Bienen der italienischen Population zugeordnet wurden (Tab. III und Abb. 3). Die PCA Analysen zeigten, dass sich bei Berücksichtigung von vier Gruppen die kroatischen Subpopulationen unterschiedlich zuordnen, wobei Subpopulation-2 eher den italienischen Bienen und Subpopulation-1 eher einigen griechischen Proben angenähert war (Abb. 4). Genetische Introgression aus der benachbarten $A$. m. ligustica in Italien wurde beobachtet, da 14,7 \% der kroatischen Subpopulation-2 der italienischen Population zugeordnet wurden (Abb. 3).

Der C2c Haplotyp wurde auch in Slowenien gefunden (Sušnik et al., 2004), womit eine enge Verwandtschaft zwischen der kroatischen und slowenischen Population teilweise bestätigt wurde. Dies geht wahrscheinlich auf den beidseitigen Austausch von Bienenmaterial zwischen Imkern zurück. Aus dem Auftreten von zwei Haplotypen, die für andere Unterarten charakteristisch sind, werden Einkreuzungseffekte abgeleitet, die entweder auf natürliche Weise zustande kommen, oder auf menschlichen Einfluss durch Königinnenhandel zurückgehen. Die Anwesenheit von zwei verschiedenen kroatischen Haplotypen in der dalmatischen Region wurde gezeigt: Subpopulation-1 kommt in nördlicheren Gebieten vor, während Subpopulation-2 im südlichen Teil des Gebiets auftritt. Die molekulare Analyse der kroatischen Honigbienen belegt die Notwendigkeit für ähnliche molekulare Untersuchungen von Bienenpopulationen in benachbarten Regionen, wo noch größere Vorkommen der autochthonen Carnica-Biene existieren.

\section{Honigbiene / mitochondriale DNA / Mikrosatel- liten / Kroatien / Struktur von Populationen}

\section{REFERENCES}

Cánovas F., De la Rúa P., Serrano J., Galián J. (2008) Geographic patterns of mitochondrial DNA variation in Apis mellifera iberiensis (Hymenoptera: Apidae), J. Zool. Syst. Evol. Res. 46, 24-30.

Crozier R.H., Crozier Y.H. (1993) The mitochondrial genome of the honey bee Apis mellifera: complete sequence and genome organisation, Genetics 133, 97-117.

Dall'Olio R., Marino A., Lodesani M., Moritz R.F.A. (2007) Genetic characterization of Italian honeybees, Apis mellifera ligustica, based on microsatellite DNA polymorphisms, Apidologie 38, 207-217.

De la Rúa P., Galián J., Serrano J. (1998) Mitochondrial variability of honeybees populations from the Canary Islands, Mol. Ecol. 7, 1543-1547.

De la Rúa P., Galián J., Serrano J. (1999) Varibilidad mitocondrial en poblaciones de abejas de la miel del Sureste Peninsular, Invest. Agr. Prod. Sanid. Anim. 14, 24-30.

De la Rúa P., Galián J., Serrano J., Moritz R.F.A. (2001) Genetic structure and distinctness of Apis mellifera L. populations from the Canary Islands, Mol. Ecol. 10, 1733-1742.

De la Rúa P., Simon U.E., Tilde A., Mortiz R.F.A., Fuchs S. (2000) MtDNA variation in Apis cerana populations from the Philippines, Heredity 84, 124-130.

Engel M.S. (1999) The taxonomy of recent and fossil honey bees (Hymenoptera: Apidae, Apis), J. Hymenop. Res. 8, 165-196.

Estoup A., Garnery L., Solignac M., Cornuet J. (1995) Microsatellite variation in honey bee (Apis mellifera L.) populations: Hierarchical genetic structure and tests of infinite allele and stepwise mutation models, Genetics 140, 679-695.

Evanno G., Regnaut S., Goudet J. (2005) Detecting the number of clusters of individuals using the software STRUCTURE: a simulation study, Mol. Ecol. 14, 2611-2620.

Franck P., Garnery L., Solignac M., Cornuet J.-M. (1998) The origin of West European subspecies of honeybees (Apis mellifera) new insights from 
microsatellite and mitochondrial data, Evolution 52, 1119-1134.

Franck P., Garnery L., Celebrano G., Solignac M., Cornuet J.-M. (2000a) Hybrid origins of honeybees from Italy (Apis mellifera ligustica) and Sicily (A. m. sicula), Mol. Ecol. 9, 907-921.

Franck P., Garnery L., Solignac M., Cornuet J.-M. (2000b) Molecular confirmation of a fourth lineage in honeybees from the Near East, Apidologie 31, 167-180.

Garnery L., Cornuet J.-M., Solignac M. (1992) Evolutionary history of the honey bee (Apis mellifera L.) inferred from mitochondrial DNA analysis, Mol. Ecol. 1, 145-154.

Garnery L., Franck P., Baudry E., Vautrin D., Cornuet J.-M., Solignac M. (1998) Genetic biodiversity of the west European honeybee (Apis mellifera mellifera and A. m. iberica). I. Mitochondrial DNA, Genet. Sel. Evol. 30, 31-47.

Garnery L., Mosshine E.H., Oldroyd B.P., Cornuet J.-M. (1995) Mitochondrial DNA variation in Moroccan and Spanish honey bee populations, Mol. Ecol. 4, 465-471.

Garnery L., Solignac M., Celebrano G., Cornuet J.-M. (1993) A simple test using restricted PCR-amplified mitochondrial DNA to study the genetic structure of Apis mellifera L, Experientia 49, 1016-1021.

Garnery L., Vautrin D., Cornuet J.-M., Solignac M. (1991) Phylogenetic relationships in the genus Apis inferred from mitochondrial DNA sequence data, Apidologie 22, 87-92.

Jensen A.B., Palmer K.A., Boomsma J.J., Pedersen B.V. (2005) Varying degrees of Apis mellifera ligustica introgression in protected populations of the black honeybee, Apis mellifera mellifera, in northwest Europe, Mol. Ecol. 14, 93-106.

Moritz R.FA., Härtel S., Neumann P. (2005) Global invasions of the western honeybee (Apis mellifera) and the consequences for biodiversity, Ecoscience 12, 289-301.
Peakall R., Smouse P.E. (2006) GENALEX 6: genetic analysis in Excel. Population genetic software for teaching and research, Mol. Ecol. Notes 6, 288295.

Pritchard J.K., Stephens M., Donnelly P.J. (2000) Inference of population structure using multilocus genotype data, Genetics 155, 945-959.

Raymond M., Rousset F. (1995) GENEPOP (version 1.2): population genetics software for exact tests and ecumenicism, J. Hered. 86, 248-249.

Ruttner F. (1988) Biogeography and Taxonomy of Honeybees, Springer Verlag, Berlin.

Ruttner F. (1992) Naturgeschichte der Honigbienen, Ehrenwirth Verlag, München.

Sheppard W.S., Meixner M.D. (2003) Apis mellifera pomonella, a new honey bee subspecies from Central Asia, Apidologie 34, 367-375.

Sinacori A., Rinderer T.E., Lancaster V., Sheppard W.S. (1998) A morphological assessment of Apis mellifera from Palermo, Italy, Apidologie 29, 481-490.

Sušnik S., Kozmus P., Poklukar J., Meglič V. (2004) Molecular characterisation of indigenous Apis mellifera carnica in Slovenia, Apidologie 35, 623-636.

Tamura K., Dudley J., Nei M., Kumar S. (2007) MEGA4: Molecular Evolutionary Genetics Analysis (MEGA) software version 4.0, Mol. Biol. Evol. 24, 1596-1599.

Walsh P.S., Metzqer D.A., Higuchi R. (1991) Chelex 100 as a medium for simple extraction of DNA for PCR-based typing from forensic material, Biotechniques 10, 506-512.

Whitfield C.W., Behura S.K., Berlocher S.H., Clark A.G., Johnston J.S., Sheppard W.S., Smith D.R., Suarez A.V., Weaver D., Tsutsui N.D. (2006) Thrice out of Africa: ancient and recent expansions of the honey bee, Apis mellifera, Science 314, 642-645. 